\title{
THE ARTIFICIAL AIR IONIZATION EFFECT (NEGATIVE AND POSITIVE) IN EXPERIMENT ON SOME HEMATOLOGICAL PARAMETERS OF WISTAR RATS *
}

\author{
Iu. Simionca, L.Enache \\ National Institute of Rehabilitation, Physical Medicine and Balneoclimatology
}

1. INTRODUCTION

\subsection{General considerations on the air ionization}

The air near the ground, where the most organisms live, is characterized by physicalchemical and biological properties.All these factors (e.g. temperature, humidity, air ionization, etc) perform certains roles and any quantitative and qualitative change, beyond certain limits, are felt on the body in one form or another.

From the physical factors of the air, the electrical power includes, in turn, electrical conductivity, electric field, electrical potential gradient, thunderstorms, air ionization, atmospherical which manifests itself differently in beautiful weather (low cloud, little wind, no precipitation ) or the disturbed weather (storm).

The most common electricity of beautiful weather, is characterized by a multitude of meanings with has direct or indirect effects on the living world, favorable or unfavorable, perceptible or not, depending on the intensity, duration or frequency of manifestation of that power factor.

A special place of these biometeorological factors is occupied by the category natural air ionization. The first observations on the existence of gaseous ions in air have been made since the early twentieth century '30 (German physicist Panthenier Ladenburg and French), thorough research and then resumed after the 50 s of various collective (including French physicist J. Bricard, University of Paris). They have highlighted the link between low ion content in the air and micropopulation atmosphere and that lack almost daily a minimum amount of negative ions of oxygen from small places of daily activities constitute a cause of a inevitable occurrence of disorders, often severe, health status.

Thus, it is confirmed that the presence of ions in atmospheric air is essential for life, since their content was found to decrease below a certain threshold value (or worse, their absence) has a negative impact on living organisms (or even their death). A large number of subsequent research have confirmed the link between this parameter of air power and a range of biological effects manifested at various stages of organization in the world live at the cellular level to the body. These influences are possible because living organisms manifests itself in a very large number of phenomena such as electricity with essential biological role (e.g, biochemical reactions, transmembrane transport of the substance of the nervous impulse propagation and others).

However, based on these findings, it was concluded that under the atmosphere of ionized artificially controlled exposure, can ensure relatively easy conditions for recovery of these environmental factors influence by induction of favorable therapeutic treatment on the body .

\subsection{Theoretical aspects of natural and artificial air ionization.}

The air ionization is the result of a number of physical factors on the one side, and air molecules, on the other side.

The main physical factors of ionization ambient air generators are represented by the natural radioactive elements from soil and air, and cosmic radiation, corpuscular radiation $(a, b)$ and electromagnetic (g, X-ray) emitted directly or indirectly provides energy for ionization of molecules neutral gas and water vapor in the atmosphere.

The molecules ionization phenomenon is complex and takes place in several stages, which can generates various air ions at the end of this . They can be both polarities (positive or negative) and may have different dimensional distributions and electrical mobility, which makes possible the classification of air ions in several categories (low, intermediate and high).

In the initial phase, primary ions are produced, such as those of oxygen in the form:

$$
\mathrm{e}^{-}+\mathrm{O}_{2}+(\mathrm{M}) \rightarrow \mathrm{O}_{2}^{-}+(\mathrm{M})
$$

where $e^{-}$is an electron-extracted (by ionizing radiation) from a neutral molecule, and $\mathrm{M}$ is any molecule, that takes place the reaction (1).

If electrons have sufficient kinetic energy, then other ions may appear, such as:

$$
\mathrm{e}^{-}+\mathrm{CO}_{2} \rightarrow \mathrm{O}^{-}+\mathrm{CO}
$$

or:

$$
\mathrm{e}^{-}+\mathrm{H}_{2} \mathrm{O} \rightarrow \mathrm{H}^{-}+\mathrm{OH}
$$


and if $O^{-}$still has enough energy, can produce a reaction with this form:

$$
\mathrm{O}^{-}+\mathrm{H}_{2} \mathrm{O} \rightarrow \mathrm{OH}^{-}+\mathrm{OH}
$$

In a later stage the primary ions, associated with other molecules or undergo reactions that lead to other types of ions, such as:

$$
\mathrm{OH}^{-}+\mathrm{H}_{2} \mathrm{O}+\mathrm{X} \rightarrow \mathrm{OH}^{-}\left(\mathrm{H}_{2} \mathrm{O}\right)+\mathrm{X}
$$

where $X$ is a certain molecule.

Following this suite of reactions, in the atmosphere may occur gaseous ions as: $\mathrm{H}^{+}\left(\mathrm{H}_{2} \mathrm{O}\right),\left(\mathrm{H}_{3} \mathrm{O}\right)^{+}$ $\left(\mathrm{H}_{2} \mathrm{O}\right), \mathrm{O}_{2}^{-}\left(\mathrm{H}_{2} \mathrm{O}\right)_{\mathrm{n}}, \mathrm{OH}^{-}\left(\mathrm{H}_{2} \mathrm{O}\right)_{\mathrm{n}}$ and others.

The ions categories and their concentrations existing in free atmosphere depend on: the intensity (energy) of the ionizing agent, local weather conditions, the degree of pollution of of atmosphere, the secondary physical ionised agents, geological and geographical location of measurement. Normally, air ions concentrations are between $500-1000$ ion $/ \mathrm{cm} 3$ in unpolluted areas outside cities, while in the city fall below 500 ioni $/ \mathrm{cm} 3$

Among these ionized secondary agents fragmentation processes of water have particular importance (breaking into small particles, spraying by fine jets of water, air bubbles breaking film from water surface evaporation process, breaking the ice crystals by the collision and others) - known processes and physical phenomena in the physics of the atmosphere, and the passage of atmospheric fronts. In these way can be generated positive and negative electric charges (depending on the chemical composition of water or material, as well as other factors), taken then the microparticles that arise these processes and phenomena.

They manifest, for example, at shore sea (under the sea foamy waves or shore), near a waterfall $(50,000$ ions $/ \mathrm{cm} 3)$, a fountain or a stormy mountain brook (8000 ions / cm3) in the rain, the blizzards and more.

Between the action of general factors and that how lead to ions recombination (destruction) is established a certain balance, reflected in a certain air ionization regime in time and place considered.

In addition to natural ionization, through various types of generating equipment can be obtained (in limited areas) ion concentrations of both polarities that can reach very large values, to several million ions / $\mathrm{cm} 3$.

There are a wide variety of air ion generators, with intensities and for different destinations, particularly to ensure the higienic character of the air. Principle of their construction and operation is very diverse, from the use of radioactive elements, devices and solutions for spraying particles or substances to that of electro rivers.

These latter system is based on producing a sufficiently intense electron flow which is immediately captured (less than one millionth of a second), mainly by oxygen molecules, making them negative ions of oxygen. Further, by trapping a few molecules of water, they become small negative ions, with identical properties to those found in nature (provided that they do not generate ozone and nitrogen oxides - considered cytotoxic peroxide).

These generators of air electricity ensures not only environmental pollution (by trapping, precipitation and sedimentation of a large number of particles of different sizes and natures, living or inert, solid or liquid), but also a bactericidal (germicidal) whereas, electrokinetic blocking mechanisms essential to the cell membrane, causing rapid death negative air ions or inactivate all existing pathogens in the air under artificial ionization (actually observed in many bacteriological research, by scientific collective Finnish, North American and Russian but also from other countries).

1.3. Biological effects and therapeutic importance of air ionization

As we seen above, the air subject to artificial ionization, which provides a sufficient density of negative ions is more salubrious than one natural.

This electrical parameter of air also presents other facets with significant biological importance. The influence of the ions start mainly from the pulmonay alveolus level and in a lesser extent from the skin.

The excess of negative electric charges carried by ions interact with both sensory nerve endings in the alveoli, and a series of blood components (RBC, some colloids), directly altering their electrical properties and stability and indirectly affecting other properties of various organic structures through numerous biochemical reactions that contribute to increased metabolism.

The studies and the research conducted till now indicates many biological and therapeutic effects. Among those most important influences are mentioned: physical and chemical properties of 
blood (low VSH's increase colloidal stability of the blood serum protein, albumin-globulin ratio decreased due to increase in the quantity globulin, blood $\mathrm{pH}$ change to alkaline, reducing the amount of sugar, decrease the accumulation of lactic acid, lowering 5 - hydroxytryptamine and others), cardio - vascular (blood pressure and cardiac pulsations number), neuro-motor system (motor nerves decrease the impact on functional status skeletal muscle, influences on EEG, disappearance of headaches, dizziness, insomnia, etc.), respiratory system (enhanced gas exchange, improving asthma bonsai, slow breathing rate and breathing pauses lengthened), skin (pain killers produced by burning, promoting healing wounds, improving the body's defense response and increase resistance to acute and chronic infectious diseases), endocrine system (regulatory effect, stimulating the formation of vitamins and their accumulation in the blood).

They also observed a number of general effects (increased appetite and, consequently, increased body mass, increasing thoracic volume, improving human performance, individuals become calmer) and bactericidal (bacteria decreased toxicity and developmental delay, accelerate death microbes, reduction of injuries microflora).

Therapeutic contraindications are few and relate to situations rarely encountered in practice.

Most often the positive ions, have actions and opposite effects than small negative ions (negative and unpleasant effects experienced by subjects due to, for example, release of serotonin).

Despite the fact that some issues are still under study, the favorable results obtained in recent years have enabled the gradual introduction and successful recovery of negative therapy of air ionizationa of a large number of diseases, especially abroad, but unfortunately in an insignificant position in our country.

\section{MATERIALS AND METHODS FOR STUDY}

To achieve the objectives of the study were selected 47 white laboratory Wistar rats line (Wistar Rats WR), male, divided into three series:

- Series I included 3 homogeneous groups, as follows: Lot 2 - composed of 7 such animals without injury infection and subjected to negative air ionization with concentration of about 15,000 / $\mathrm{cm}^{3}$ particles lot 5 - of 9 animals with injuries of skin surface to which equal to $3.0 \mathrm{~cm}^{2}$ was infected with Staphylococcus aureus, unionized, Lot 6 - 9 animals $3.75 \quad \mathrm{~cm}^{2}$ infected with those microorganism ;

- Series II - 3 respectively homogeneous lots: Lot 1 - animals without injury infection and unionized (7 animals), lot 3 - animals without wound infection and subjected to negative of about 230,000 pariticles / $\mathrm{cm}^{3}$ concentration (7 animals), lot 7 - animals with $16.3 \mathrm{~cm}^{2}$ injuries infected with microorganisms mentioned, and subject to negative air ionization of about $230,000 / \mathrm{cm}^{3}$ concentration ( 9 animals), lot 9 animals with injuries of $16.3 \mathrm{~cm}^{2}$, infected and unionizaed (7animale), lot 10 animals with injuries of $20.1 \mathrm{~cm}^{2}$, infected without air ionization, investigations after 10 days of infection and the development of inflammatory skin infectious process ( 7 animals);

Series III includes two homogeneous lots: lot 4 - animals with injuries of $13.6 \mathrm{~cm}^{2}$, clean, uninfected, subject to positive air ionization of about $230,000 / \mathrm{cm}^{3}$ particles concentration (7 animals), lot 8 - animals with injuries of $13.6 \mathrm{~cm}^{2}$ infected, subject to the same polarity and concentration air ionization ( 9 animals).

The animlas were anesthetized with pnenobarbital of $12 \mathrm{mg} / \mathrm{ml}$ solution in heparin and then on them back were caused a scaping injury that was infected with Staphyilococcus aureus from a pure culture, etiology concentration of 109 / $\mathrm{ml}$, such as the infectious process induced skin inflammation (PII).

Since the 2nd day after the beginnings of inflammatory process series $I$ and day 4 respectively of the animals in series II, were subjected for 4 daily to air ions for 3 weeks; animals were kept under standard conditions biobase.

In the table below are presented: WT groups subjected to study, polarity and artificial air ions concentration generated for application on laboratory animals in the experiment, average area of cutaneous injury and observations regarting to their inflammation with microorganism conditionally pathogenic-Staphylococccus aureus 
Table1. Lots of white rats WR

\begin{tabular}{|c|c|c|c|c|c|}
\hline $\begin{array}{c}\text { Name } \\
\text { Lot WR }\end{array}$ & $\begin{array}{c}\text { Marking } \\
\text { lots }\end{array}$ & Ionization type & $\begin{array}{c}\text { Particles and ions } \\
\text { concentration }\end{array}$ & $\begin{array}{c}\text { WR with and } \\
\text { without injuries }\end{array}$ & $\begin{array}{c}\text { Specific } \\
\text { characterization } \\
\text { of WR lots }\end{array}$ \\
\hline S2L1 & & Without ionization & 0 & Without injury & Control \\
\hline S1L2 & & Negative & 15.000 & Without injury & Uninfected \\
\hline S2L3 & Negative & 230.000 & Without injury & Uninfected \\
\hline S1L5 & Without ionization & 0 & 3.0 & $\begin{array}{c}\text { Infected with } \\
\text { Staph. aureus }\end{array}$ \\
\hline S2L9 & Without ionization & 0 & 16.3 & $\begin{array}{c}\text { Infected with } \\
\text { Staph. aureus, }\end{array}$ \\
\hline S2L10 & Without ionization & 0 & 20.1 & $\begin{array}{c}\text { Infected with } \\
\text { Staph. aureus; } \\
\text { investigations } \\
\text { after 10 days }\end{array}$ \\
\hline S1L6 & & Negative & 15.000 & 3.75 & $\begin{array}{c}\text { Infected with } \\
\text { Staph. aureus }\end{array}$ \\
\hline S2L7 & & Negative & 230.000 & 16.3 & $\begin{array}{c}\text { Infected with } \\
\text { Staph. aureus }\end{array}$ \\
\hline S3L4 & & Positive & 230.000 & 13.6 & Uninfected \\
\hline S3L8 & & Positive & 230.000 & 13.6 & $\begin{array}{c}\text { Infected with } \\
\text { Staph. aureus }\end{array}$ \\
\hline
\end{tabular}

Air ionization of cutaneous surface with and without PII was performed using an ion generator with possibilities to generate 15000230000 negative / positive ions $/ \mathrm{cm}^{3}$.

Was made the following tests on laboratory animals (WR):

1. The assesment of WBC blood concentration by photon microscopy method Bürker room and expressing of cell number in $\mathrm{l} / \mathrm{ml}\left(\mathrm{nx} 10^{* 9} / \mathbf{l}\right.$ sau $\left.\mathrm{nx10} *{ }^{9} / \mathrm{ml}\right)$ and various WBC by photon microscophy of blood blades fixed by May Grünvald methodology and expression of the results in relative (\%) and absolute $(n \times 10 * 9 / 1)$ values.

2. Hematocrit determination by micromethod (Micro Haematocrit Tubes Modulohm A/S, Denmark).

\section{RESULTS}

Results of hematological investigations on white Wistar rats, with and without inflamed injuries, subject to the action of various schemes with artificial ionization positive and negative polarity were compared with some from literature (Jaskowski, J. and Mysliwski, A., 1986; Guidelines for Collection of Blood from Experimental Animals. University of Minnesota, USA. HTML Document, 2006; Hematological Values for Long Evans Rats. Hematological Values for Wistar-Kyoto Rats. TACONIC. ANTECH diagnosis, 10 Executive
Blvd. Farmingdele. Nz 11735. HTML Document, 2006; Puggina Rogato Gustavo, Elite Luciano, 2006).

Analysis of these data allowed to highlight some changes in the immune system. Should be noted that the blood cells WBC have an important role both in inflammation process and the immune system of animals and humans.

According to the results presented in figures 1 of 12 laboratory animals with or without skin and infected injuries, subject to artificial air ionization negative or positive at of 15,000 and 300,000 particles $/ \mathrm{cm}^{3}$ concentration was observed some changes in concentration and distribution of various forms WBC blood.

Figure 1 presents the concentration of WBC blood of laboratory animals in the experiment and figures 2-12 the realtive (\%) and absolute $\left(\mathrm{nx} 10^{*} 9 / 1\right)$ values of different WBC and those leucocytar indices.

In control and uninfected lots of WR (S2L1without ionization and injury, uninfected), but subject to negative air ionization with 15,000 particles $/ \mathrm{cm}^{3}$ (S1L2) there were no pathological changes in blood WBC concentrations.

It was found a decrease in the concentration of WBC blood of laboratory animals without skin injury and uninfected but subjected to negative air ionization with 230,000 particles $/ \mathrm{cm}^{3}$ (S2L3 group) and those with experimental injury skin surface, subsequently infected with suspension of Staph. aureus (lot S2L7). 
Figure 1.

Concentrația de neutrofile $\left(n \times 10^{*} 9 / 1\right)$ în sânge la şobolanii albi Wistar din diferite loturi sub acțiunea aeroionizării artificiale

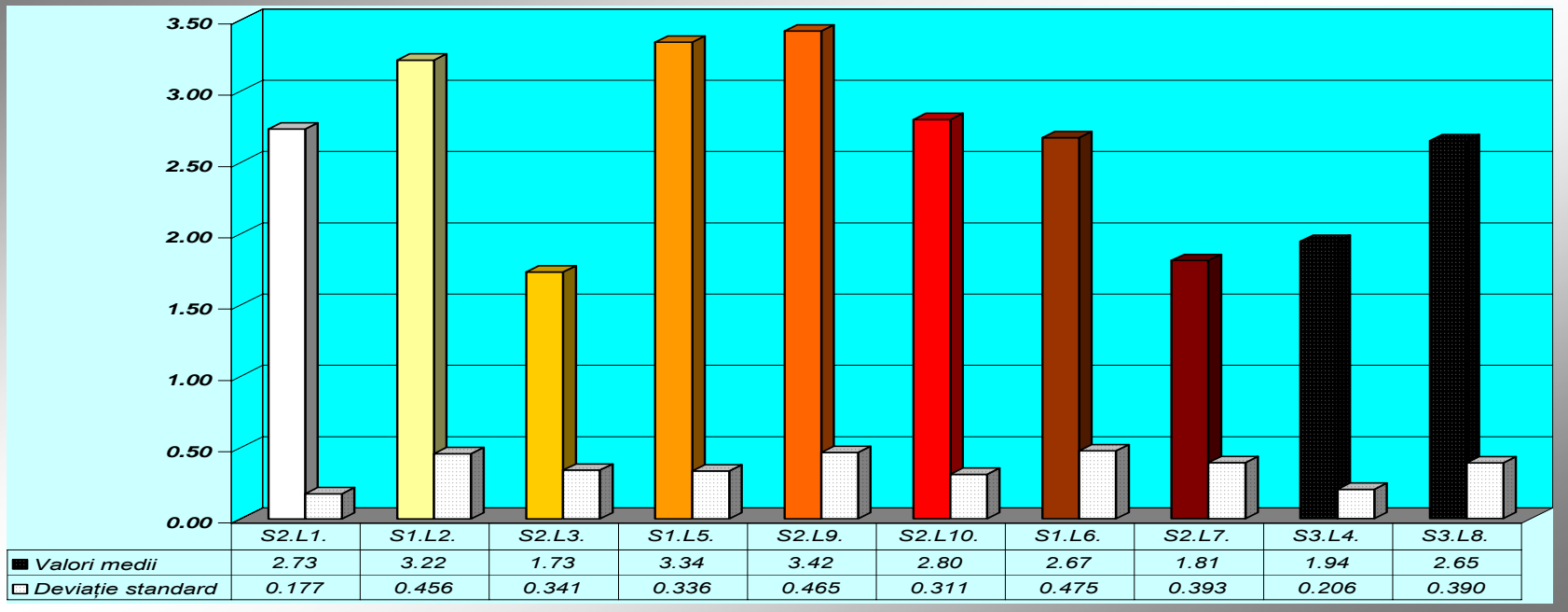

Figure 2.

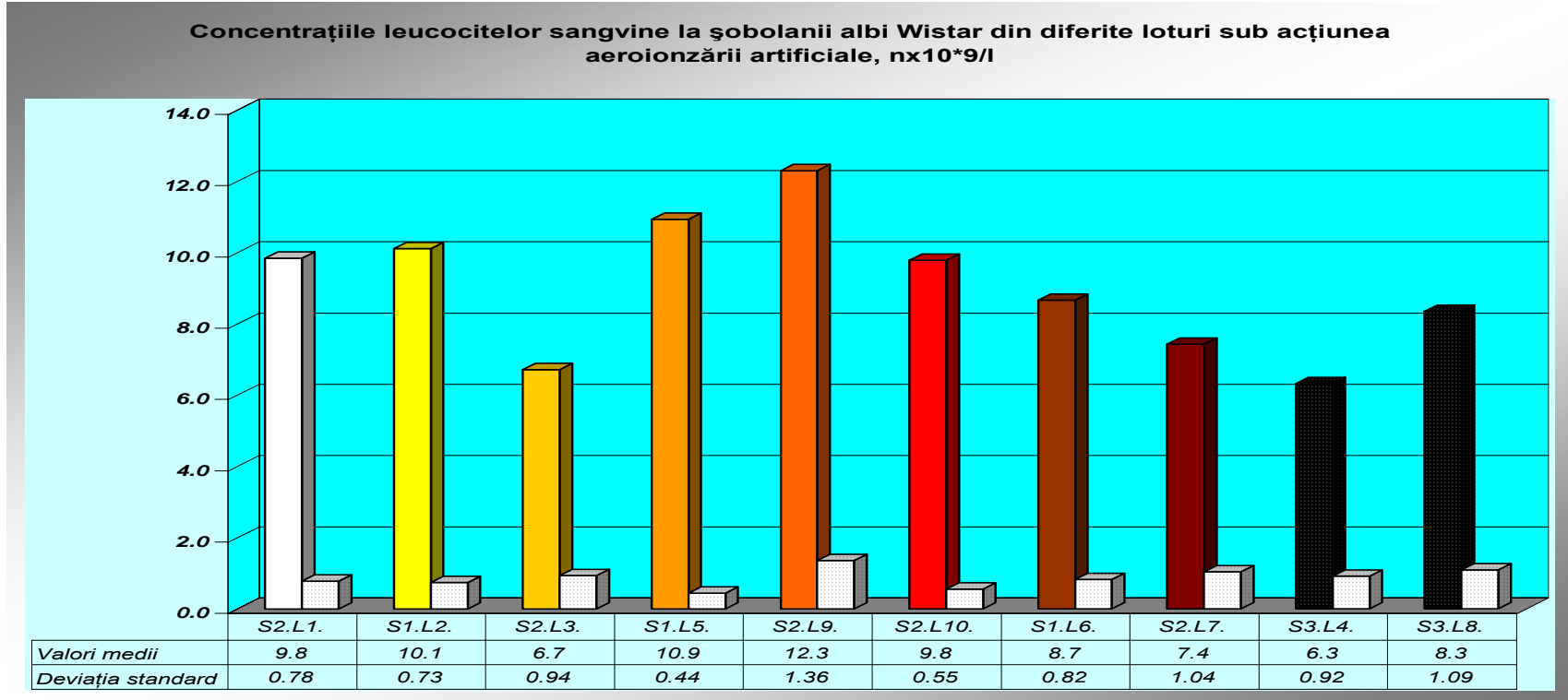

Figure 3.

Concentrația ( \% ) de neutrofile nesegmentate în sânge la şobolanii albi Wistar sub acțiunea aeroionizării artificiale

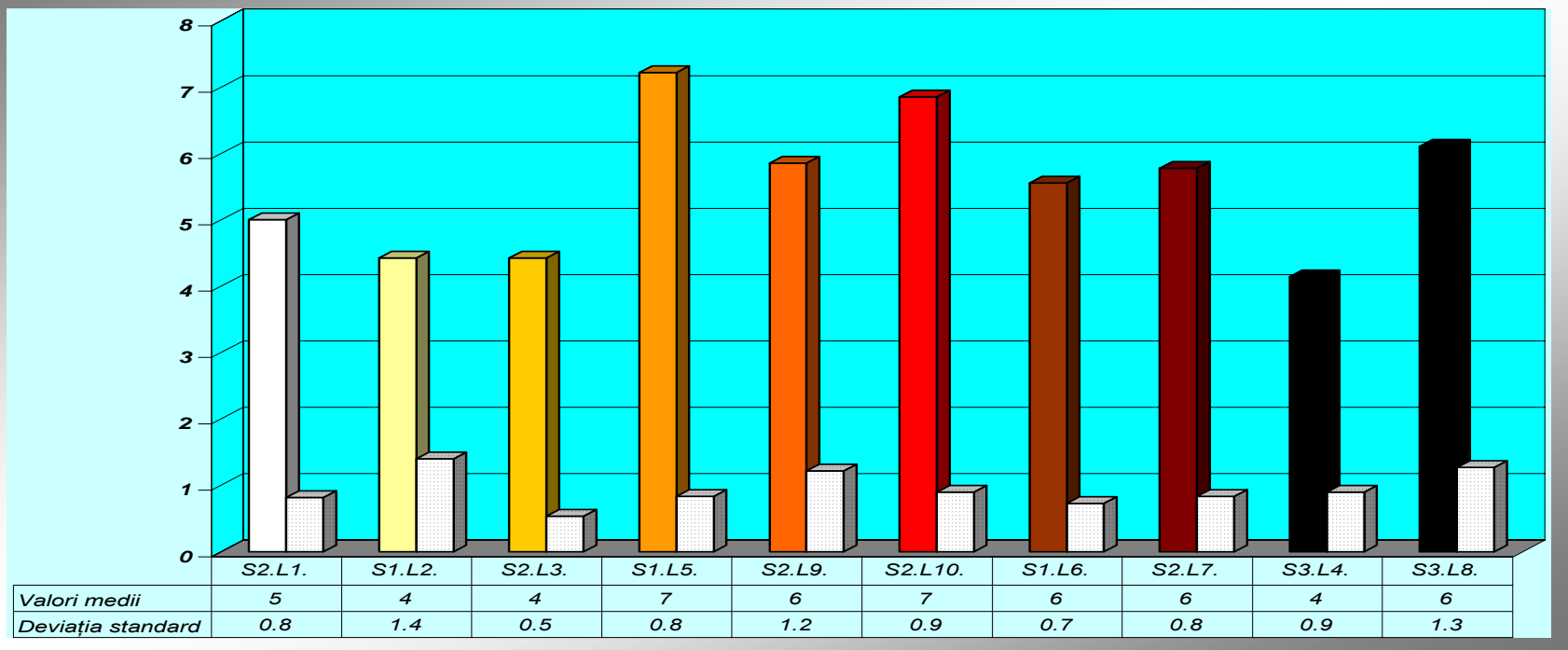


Similar results were observed to groups of animals subjected to positive artificial air ionization of 230,000 particles $/ \mathrm{cm}^{3}$ (lot S3L4), although should be noted that in the presence of infected injuries concentrations of WBC blood (lots S1L6 and S3L8) are just a decrease trend.

The increase of WBC concentration occured of rats lots with $3.0 \mathrm{~cm}^{2} 16.3 \mathrm{~cm}^{2}$ injuries experimentally infected with microoorganisme but unionized (lots S1L5 and S2L9); insignificant of animals after 10 days of infection (S2L10 lot).

The figures 2 to 6 present the neutrophils concentrations (relative $-\%$ and $\mathrm{nx} 10^{* 9} / \mathrm{L}$ ) of investigated lots of animals.

Compared with control lots (S2L1-without ionization and injuries), the experimental lot S1L2 without infection and subjected to the negative air ionization $\left(15,000 / \mathrm{cm}^{3}\right)$ of WR in most experimental lots, including those of positive air ionization, were not found pathological changes in relative concentration (\%) by blood neutrophils, although should also mention that in animals subjected to negative air ionization with 230,000 particles $/ \mathrm{cm}^{3}$, with infected injury skin surface after experimental suspension of Staph. aureus (lot S2L7) showed a trend of decreasing concentrations of neutrophils (respectively $32+/-4.3$ and $24+/$ $2.5 \%$ ). Significantly reduced values were found in expression of blood neutrophils concentration in absolute formative elements (NX10 * 9 / L), especially of animals without skin injury (lot S2L3) and those with skin injury surface after the infection with Staph. aureus in suspension (lot S2L7), subjected to negative air ionization 230,000 particles $/ \mathrm{cm}^{3}$, and positive artificial air ionization 230,000 particles $/ \mathrm{cm}^{3}$ (lot S3L4).

Instead, the trend of increasing absolute concentration of neutrophils $(\mathrm{NX10} * 9 / \mathrm{L})$ in blood was observed on WR with injury batches of
$3.0 \mathrm{~cm}^{2} 16.3 \mathrm{~cm}^{2}$ experimentally infected with microoorganisms but ionized (lots S1L5 and S2L9) , which may be due to nonspecific reaction of the body to infectious-inflammatory process.

Compared with control lots (S2L1- without ionization and injury), the experimental lot S1L2 with uninfected injury and subjected to negative air ionization $\left(15,000 / \mathrm{cm}^{3}\right)$ on most experimental groups of WR, including those subjexted to positive air ionization, were not found pathological changes in relative concentration (\%) of blood neutrophils, although we shoul note that of animals subjected to negative air ionization 230,000 particles $/ \mathrm{cm}^{3}$, with infected skin injury surface after the experiments with suspension of Staph. aureus (lot S2L7) showed a trend of decreasing in neutrophils concentrations (ie $32+/-4.3$ and $24+/-2.5 \%$ ).

Significantly reduced values were found in expression of the concentration of blood neutrophils in absolute formative elements (NX10 * 9 / L), especially of animals without skin injury (lot S2L3) and those with skin injury surface after the infection with Staph. aureus in suspension (lot S2L7), subjected to negative air ionization 230,000 particles $/ \mathrm{cm}^{3}$, and positive artificial air ionization 230,000 particles / $\mathrm{cm}^{3}$ (lot S3L4).

Instead, the trend of increasing absolute concentration ( neutrophils NX10*9/L) in blood was observed on WR with injury batches of $3.0 \mathrm{~cm}$ ${ }^{2} 16.3 \mathrm{~cm}^{2}$ experimentally infected with, which may be due to nonspecific reaction of the body to infectious-inflammatory process.

Significant changes were observed in the fractional concentrations of nonsegmented and segmented neutrophils (polymorphonuclear neutrophils - PMN). (Figures 3 and 4). 
Figure 4.

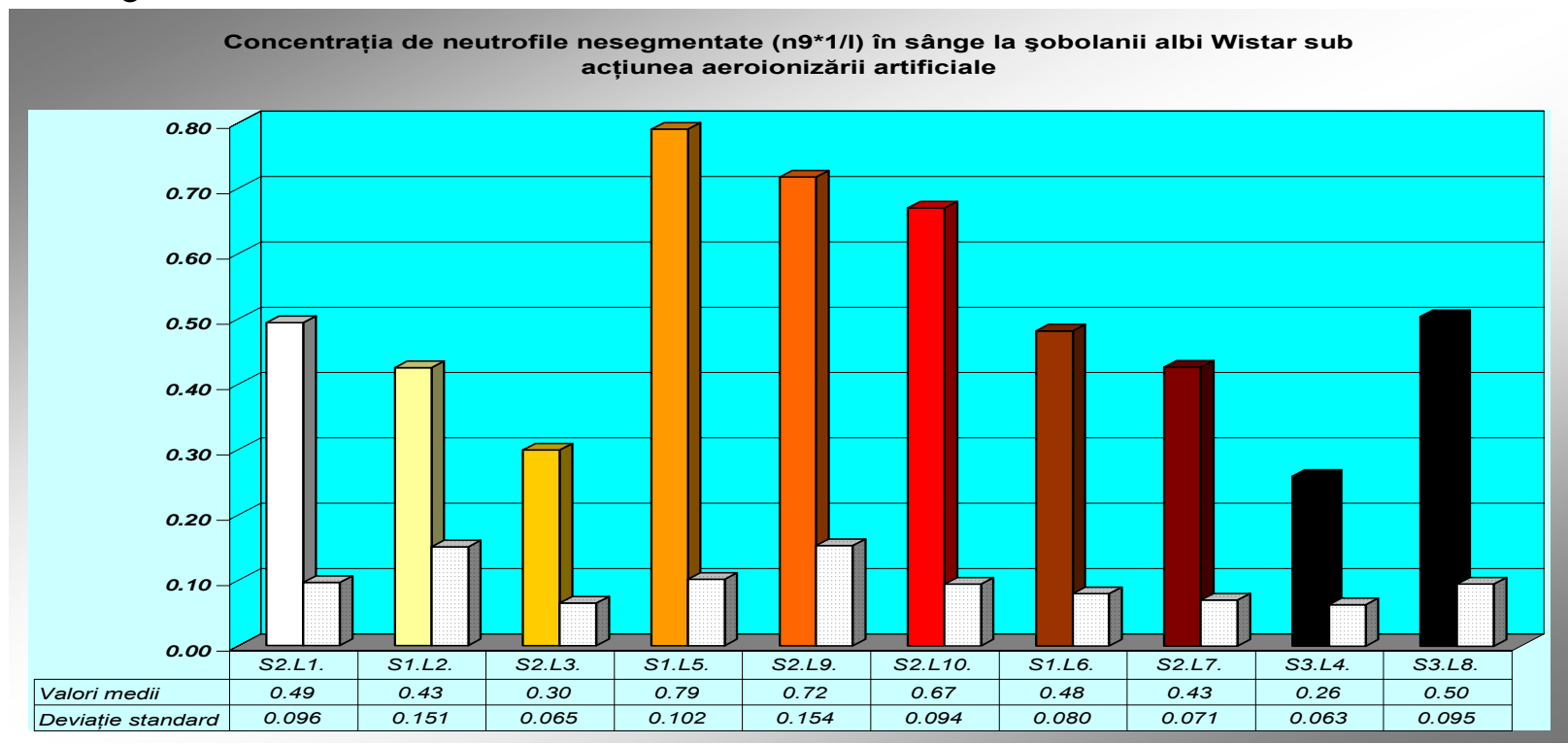

Figure 5.

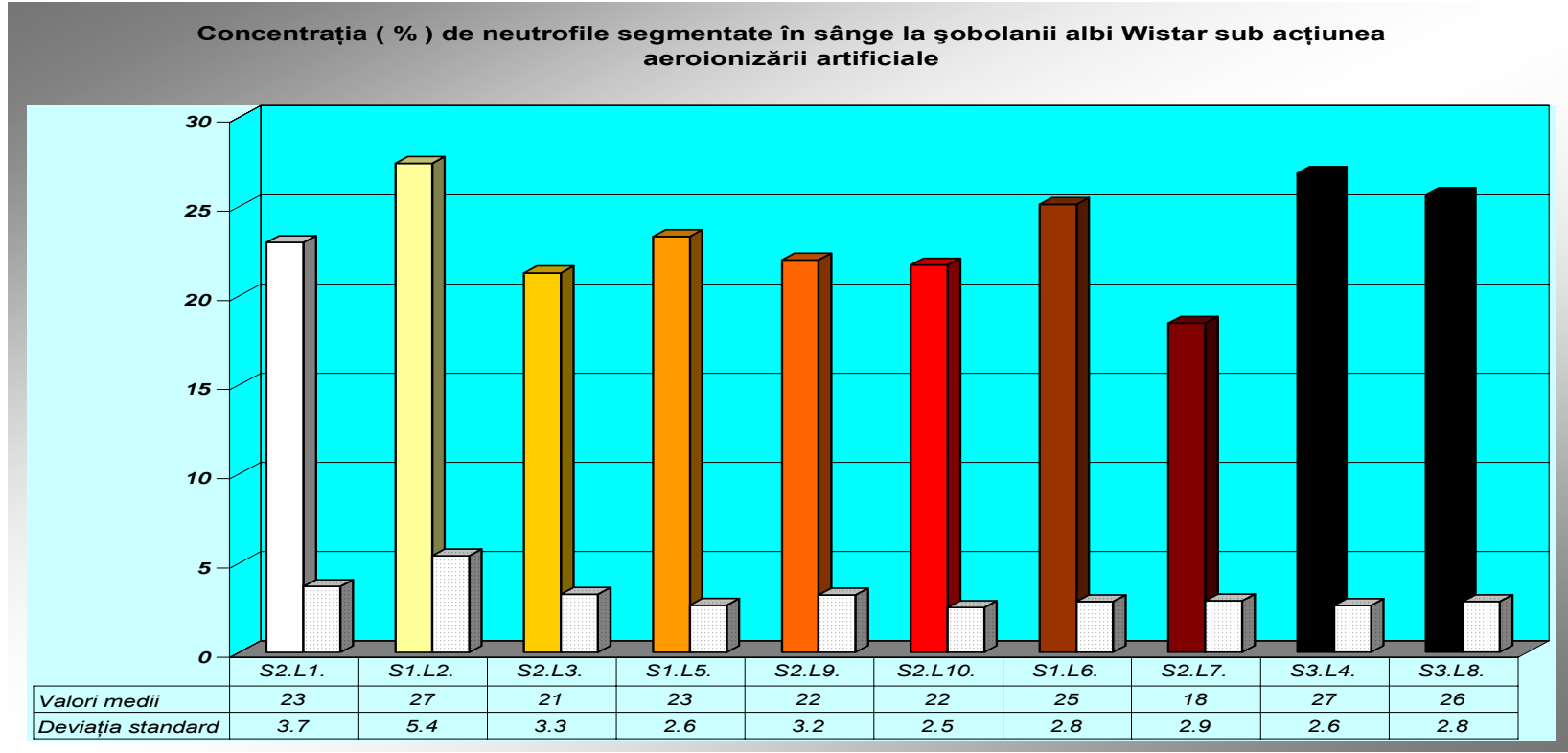

Figure 6.

Concentrația de neutrofile segmentate $\left(n \times 10^{*} 9 / 1\right)$ în sânge la şobolanii albi Wistar din diferite loturi sub acțiunea aeroionizării artificiale

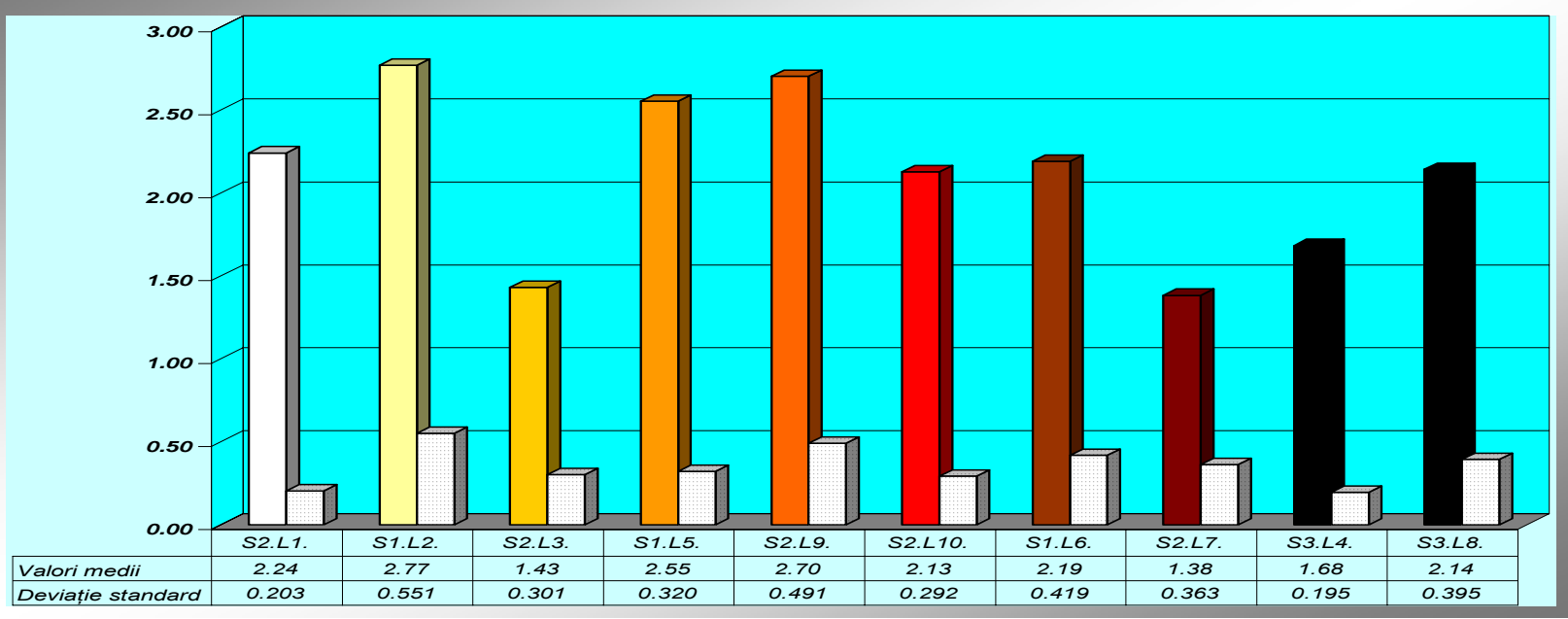


We should note that WR from S1L5 lots (without ionization and about $3.0 \mathrm{~cm}^{2}$ infected injuries with Staph. aureus), S2L9 (no ionization, but infected injuries of $16.3 \mathrm{~cm}^{2}$ average) and S2L10 (without ionization, after 10 days with infected injuries of $20.1 \mathrm{~cm}{ }^{2}$ average), so in the presence of acute inflammatory and infectious process, lasting 10 days, the concentration of the nonsegmented neutrophils $(\mathrm{P}<0.05)$ expressed both in relative $(\%)$ and absolute values $(\mathrm{NX10} * 9 / 1)$ was significantly increased, observing the forms and cases of immature and neutrophil precursors. Under the action of negative air ions of about 15,000 particles $/ \mathrm{cm}^{3}$ in the blood of investigated animals from different experimental lots were not found pathological changes in relative values (\%). Of animals from S1L6 lots (with infected injuries, subject to negative air ionization of $15,000 / \mathrm{cm}^{3}$ concentration) was observed only the trend of increasing in concentration of the nonsegmented neutrophils $(\mathrm{P}>0.1)$, expressed in relative values $(\%)$. Were found low absolute values (NX10*9/ L) of nonsegmented blood neutrophil to WR from lots S2L3 (uninfected, subject to negative air ionization of 230,000 particles $/ \mathrm{cm}^{3}$ concentration) and S3L4 (uninfected, subject to positive air ionization of 230,000 particles $/ \mathrm{cm}^{3}$ concentration) and for S2L7 and S3L8 lots (with infected injuries, subject to positive and negative air ionization of $230,000 / \mathrm{cm}^{3}$ concentration) - the trend of relative concentration increasing (\%) of nonsegmented neutrophils $(\mathrm{P}>0.1)$.

In terms of concentration variations of segmented neutrophils (PMN), it is noteworthy that at WR of $3.0 \mathrm{~cm}^{2}$ infected with Staph. aureus but unionized, and on animals with infected injuries of $16.3 \mathrm{~cm}^{2}$, but without applying air ionization (lot S2L9) was found an increase of PMN neuterofile in blood concentration.

After the negative air ionization of about $15,000 / \mathrm{cm}^{3}$ paticles (lot S1L2) at WR without injuries and uninfected has been found a growing trend in the number of PMN cells in the blood. After the negative air ionization of about 230,000 / $\mathrm{cm}^{3}$ particles there was a relative and absolute decrease in the number of PMN neutrophils in blood from both the WR group with $16 \mathrm{~cm}^{2}$ injuries infected with Staph aureus (group S2L7) as well as from animals uninfected and without injuries (lots S2L3 and S2L7) .

The trend of the number of these cells blood decreasing was observed at uninfected WER without injuries, but subjected to positive air ionization of about $230,000 / \mathrm{cm}^{3}$ (lot S3L4).

The figures 7 and 8 present the relative (\%) and absolute ( $\left.\mathrm{nx} 10^{* 9}-\mathrm{L}\right)$ concentration of blood eosinophils on WR in the experiment.
On WR with injuries and infection induced (S3L8 lot) was found a increasing trend of relative eosinophils (\%) in the blood.

In the blood of the animals from infected and uninfected, with and without injuries lots subjected to negative air ionization of about 15.000 $/ \mathrm{cm}^{3}$ (lot S1L6) and $230.000 / \mathrm{cm}^{3}$ (lots S2L3 şi S2L7) concentration and from uninfected and without injuries lot subjected to the same concentration of positive air ionization (lot S3L4) was found downward trend in relative number (\%) of eosinophils, absolute number (NX10*9/L) of these cells was significantly lower.

The concentration of relative monocytes (\%) from the blood doesn't show a significant variation. The analysis of absolute concentration results (NX10*9/L) of the blood monocytes investigated to WR is shown in figure 9.

Some changes of monocytes concentration, namely a significant decrease in absolute number (NX10 * 9/L) of blood monocytes were observed at WR from uninfected or infected injuries lots (lots S2L7, S3L4) subjected to negative and positive air ionization.

Similarly, was mentioned a downward trend in the number of these blood cells at uninflamed animals subjected to negative air ionization (lot S2L3). For the immune system of human and animals an important role is played by lymphocyte cells.

It was found that the relative concentration (\%) of WR blood lymphocytes from different investigated groups didn't suffer significant changes. Decreasing trend of blood lymphocyte was observed only for infected animals subjected to positive maximum air ionization of about 230.000 $/ \mathrm{cm}^{3}$ (lot S3L8) (respectivelly 56+/-2.1\% and $66+/-1,7-61+/-3,0 \%)$.

As regarts to the absolute values of results $(\mathrm{NX} 10 * 9 / \mathrm{L})$ was found (figure 10) that at WR with skin injuries and inflammatory process (S2L9 lot of animals with $16.3 \mathrm{~cm}^{2}$ injuries infected with Staph. aureus) observed trend of increasing the number of lymphocytes in the blood and at those with or without infected injuries and subject to positive air ionization of about 230,000 particles / $\mathrm{cm}^{3}$ (lots S3L4 and S3L8), has been a considerable decrease in the concentration of cell lymphocyte.

Similarly, was mentioned a downward trend in the absolute number of blood lymphcytes was mentioned to uninfected WR subjected to subject to maximum negative air ionization of 230.000 particles / $\mathrm{cm}^{3}$ (lot S2L3).

We also should calculate the mathematical relationships on status and inter-relations between different leukocytes. 
Figure 11 presents the data analysis of the mathematical ratio "nonsegmented neutrophils Figure 7.
/ segmented neutrophils and figure 12 the report" neutrophil / lymphocyte "

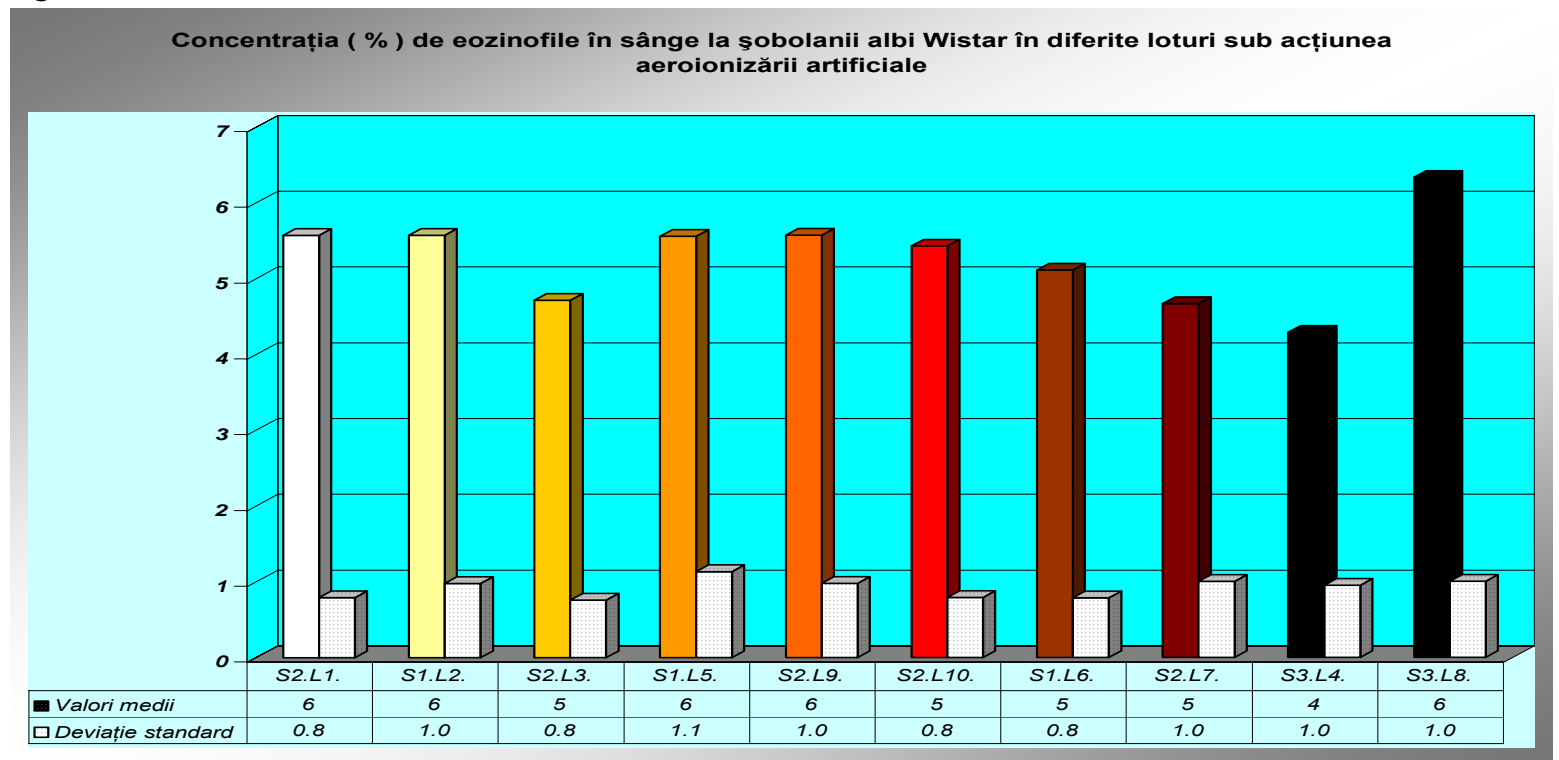

Figure 8.

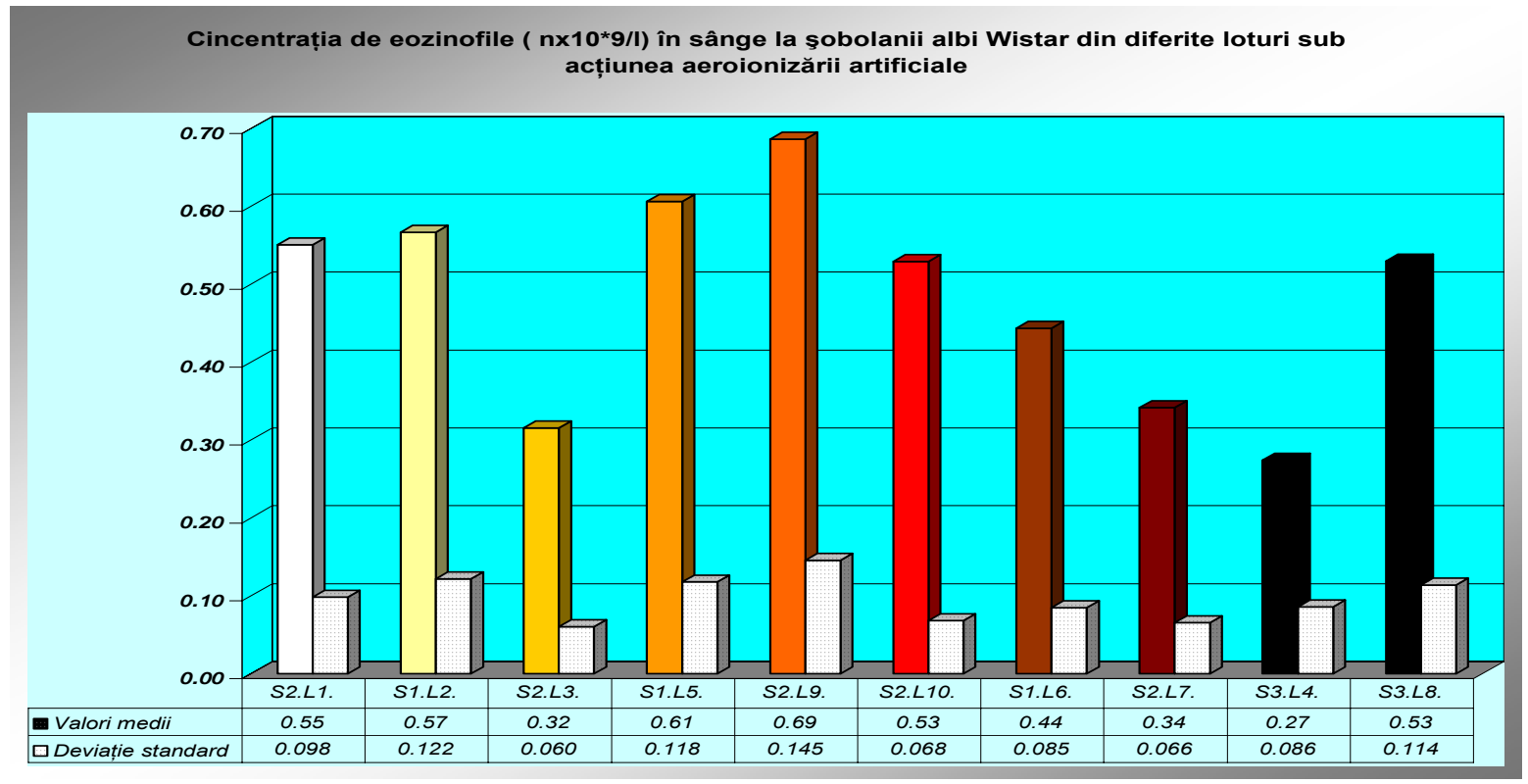

Figure 9.

Concentrația de monocite $\left(n \times 10^{*} 9 / /\right)$ în sânge la şobolanii albi Wistar din diferite loturi sub acțiunea aeroionizării artificiale

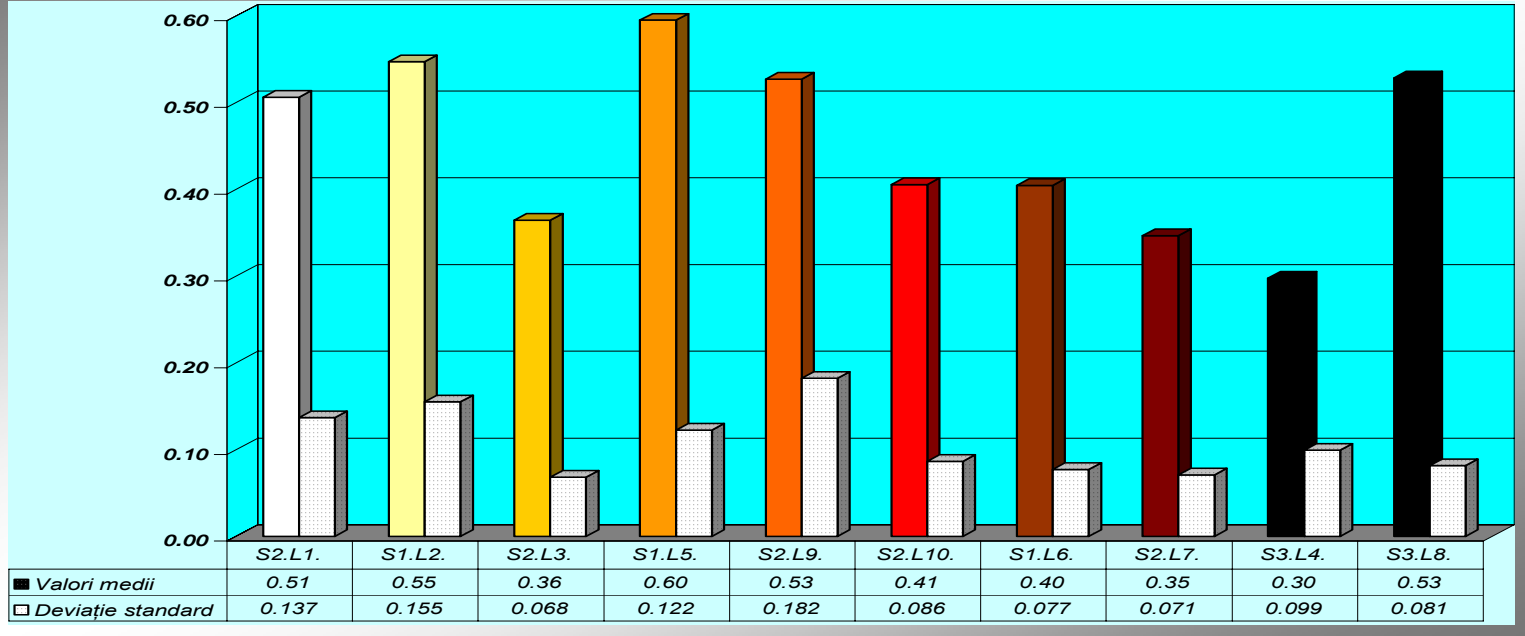


Figure 10

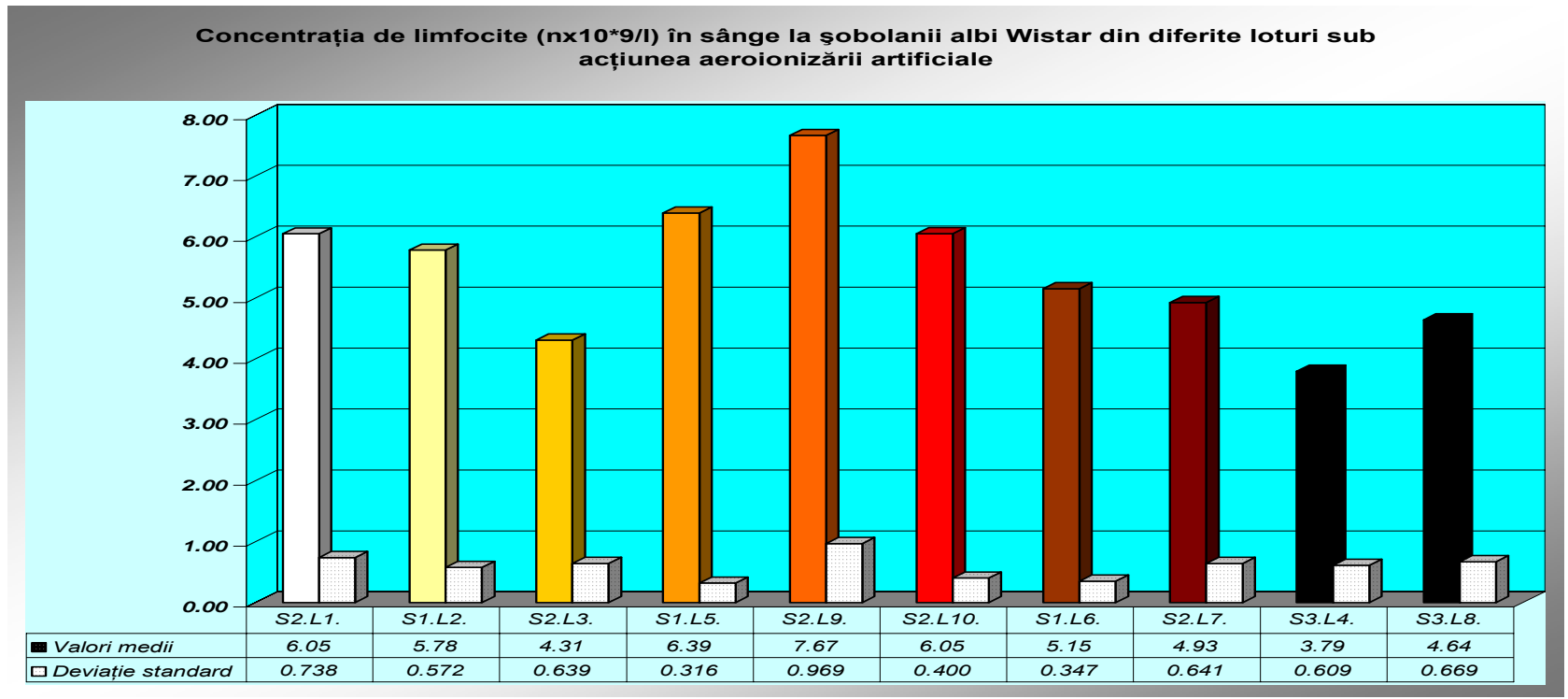

Figure 11.

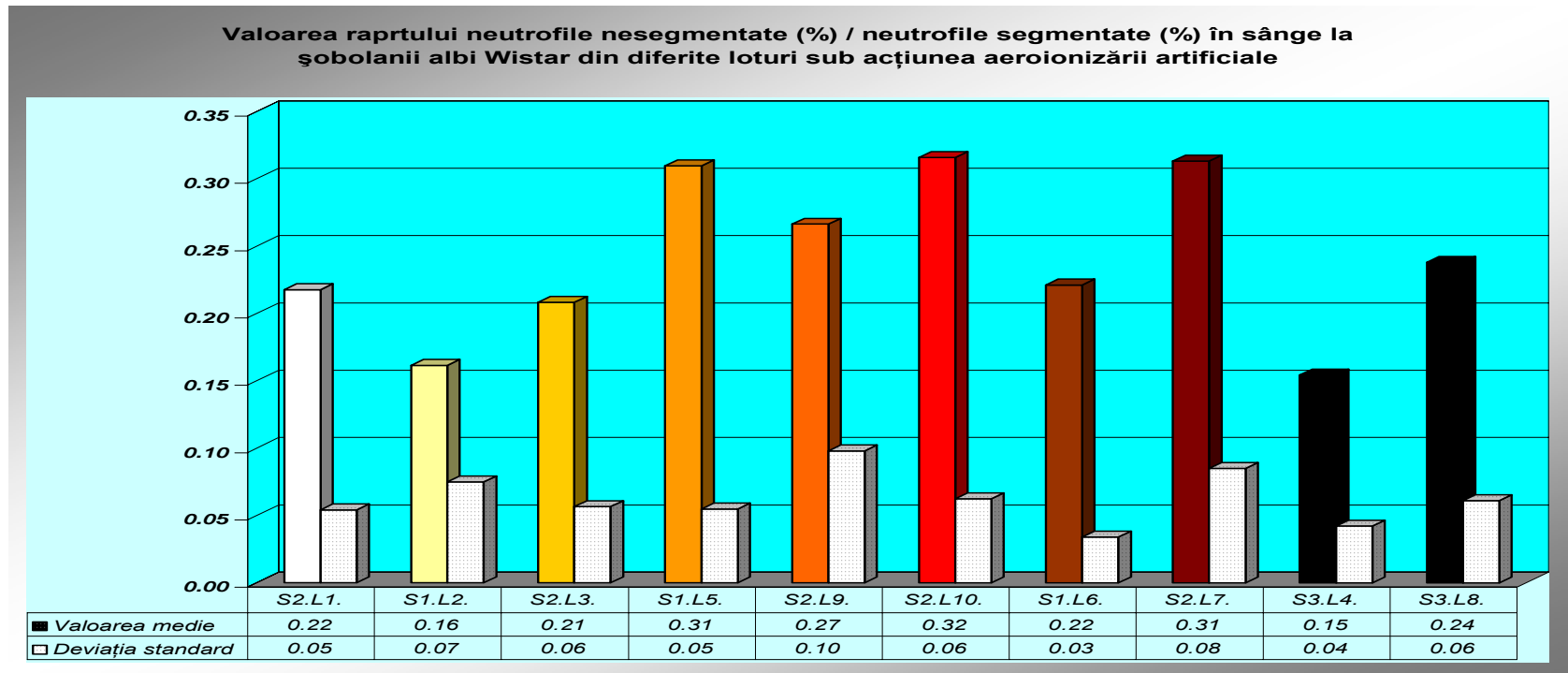

Figure 12.

Valoarea raportului neutrofile (\%) / limfocite (\%) în sânge la şobolanii albi Wistar din diferite loturi sub acțiunea aeroionizării artificiale

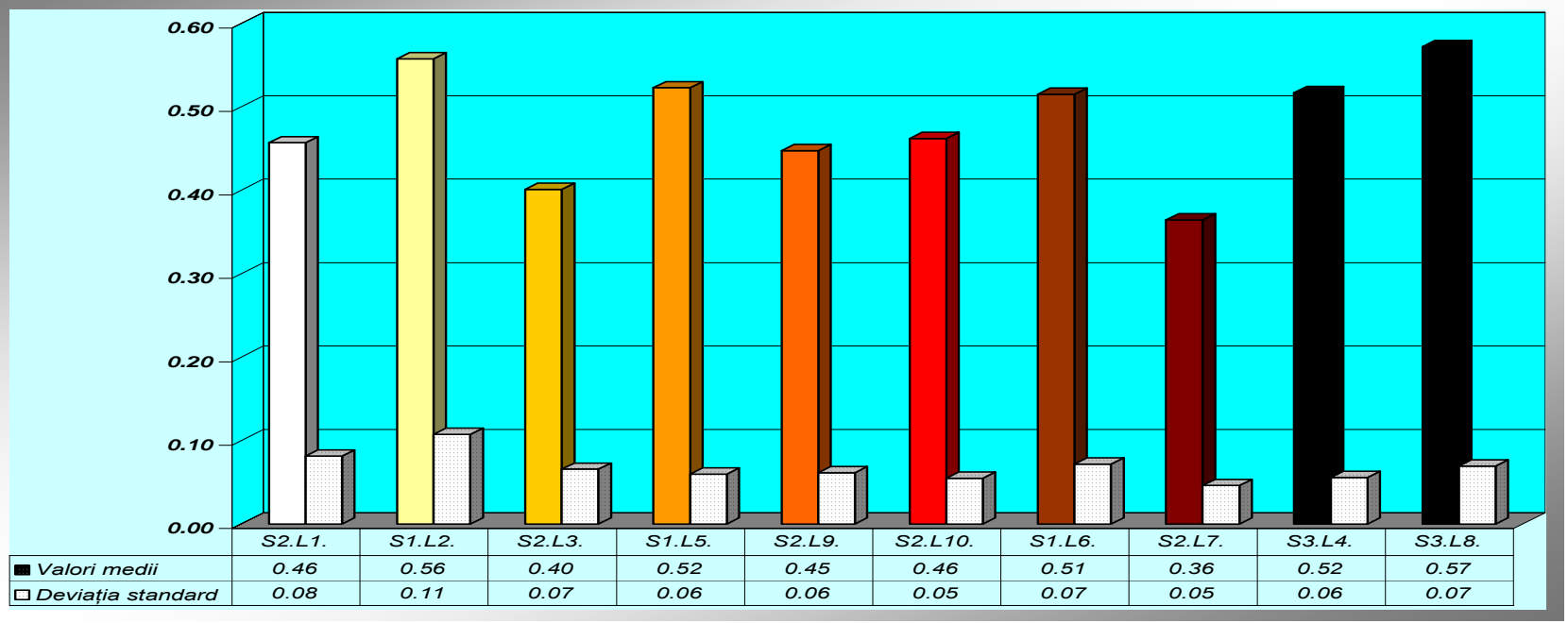


It was found that from WR lots with infected injuries without ionization (lots S1L5, S2L9, S2L10), the lot with infected injuries subjected to negative air ionization with increased concentration of about 230,000 particles $/ \mathrm{cm}^{3}$ (lot S2L7) the value ratio "nonsegmented neutrophils / neutrophil segmented" from blod has been increasing and tends to increase which indicates a neutrophil response to inflammatory process induced, characterized by the development of young or immature forms, and in group of animals with infected wounds but subject to positive air ionization of about 230,000 particles / $\mathrm{cm}^{3}$ (S3L4 lot) - the tendency of decreasing the value of that report, which could be a result of suppression of young or immature nonsegmented neutrophils.

The data from figure 12 indicate the presence of a increasing trend of "neutrophil / lymphocyte" ratio at infected WR unionized (lot S1L5) and those with infected injuries subjected to negative air ionization of 15,000 particles / $\mathrm{cm}^{3}$ (lot S1L2), which may repesent a stimulation of PMN neutrophils system. Of animals with infected injuries and subjected to negative air ionization of 230.000 particles $/ \mathrm{cm}^{3}$ was observed trend of decreasing the value of that report.

It was also found that the relative values (\%) of hematocrit from WR blood didn't differ from experimental lots. The results obtained from laboratory animals uninfected and without injuries subjected to negative air ionization of 230.000 particles $/ \mathrm{cm}^{3}$ concentration (lot S2L3 - 40,43 +/$1,27 \%$ ), and from those subjected to positive air ionization with the same increased concentration (lots S3L4 - 40,00+/-1,15\% si S3L8), shows a tendency to decrease of hematocrit value compared with the control group animals (lot S2L1) and infected lots with or without air ionization of 15.000 particles / $\mathrm{cm}^{3}$ (lots S2L9 snd S1L6) (respectivelly $40,43+/-1,27 \%$ si $40,00+/-1,15 \%$ $41,44+/-1,13 \%$ compared with 44,14+/-1,77 \% $46,71+/-1,11 \%-46,78+/-1,10 \%, \mathrm{P}<0,05)$.

\section{DISCUSSIONS AND CONCLUSIONS.}

The analysis of the results indicate a redistribution of the relative number and total concentration (NX10*9/L) in blood leukocytes and various forms of leukocyte, especially neutrophil PMN, young-nonsegmented neutrophils, and lymphocytes - as a result of an inflammatory infectious process and a organismic nonspecific response to infection and the air ionization effect with different polarity and concentration.

The data obtained are both practical and fundamental research interest and indicate the need for development of studies in this area.
*Results obtained in phase IV(Responsible-CPII Dr.b. Simionca Iuri), Project Nr.466/2004 -

2007(Project Manager- Conf. Dr. fiz. Enache Liviu)

\section{SELECTIVE BIBLIOGRAPHY}

1. Ardelean I., Barnea M., Elemente de biometeorologie medicală, Editura Medicală, Bucureşti, 1972.

2. Bach F., Hirschorn K. Lymphocyte interaction, a apotential histocompatibilitz test in vitro. "Exptl. Cell. Res", 1963, 32, 592.

3. Botea Simona, Mocanu Mihaela, Filipescu C., Tarniță Georgeta, Enache Liviu, Simionca Iu.(2005).: The effect of the artificial aeroionization on the factors with atheromatose potential.Scientific Works (Lucrări ştiințifice), Faculty of Veterinary Medicine, University of Agronomical sciences and veterinary medicine, Bucharest, 2005, C Series XLVIII, p.539-551

4. Breton J., Breton M., 1994, Phénomènes ioniques atmospheriques, micropollution et climats: des lois physiques á leur application, Climat et Santé, G.D.R., 102, CNRS, 11, p. 55 - 74.

5. Breton J., Breton V. şi Le Goff Y., 1998, Atmospheric ionisation patterns at $4 \mathrm{~m}$ above ground level in correlation to meteorological events, Journal of Geophysical Research, 103, p. $1837-1846$.

6. Breton J., Breton M., 1994, Phénomènes ioniques atmospheriques, micropollution et climats: des lois physiques á leur application, Climat et Santé, G.D.R., 102, CNRS, 11, p. 55 - 74.

7. Boulatov, P. C. (1968). "Traitement de l'asthme bronchique par l'aeroionisation négative." In: Bioclimatology, Biometeorology and Aeroionotherapy (R. Gualtierotti, I. H. Kornblueh, and C. Sirtori, eds.) Carlo Erba Foundation Publ., Milano, p. 104.

8. Danon A., şi Sulman F. G., 1969, Ionising effect of winds of ill repute on serotonin metabolism, Biometeorology 4 (Suppl. to Int. J. Biometeor.) 4, Part II, p. 135 - 136.

9. Enache L., Dacos Mariana, Crețeanu V. Studii microclimatice în Slănic Prahova şi Tg. Ocna Salt Mines. Hidrotehnica, Gosp.Apelor, meteor. XIX, 2, 1972.

10. Enache L. şi Andrişan C., 1990, Determinări privind influența aeroionizării asupra poluării aerului, I.A.N.B., Lucrări ştiințifice, seria E, XXXIII, Îmbunătățiri funciare, Bucureşti, p. 35.

11. Enache L., 1999, Ionizarea aerului şi efectele sale biologice, Sănătatea plantelor, nr. 16 (9), p.34, Bucureşti.

12. Enache, L., Biometeorologie, Editura Axa 2001, Bucureşti, 2001.

13. Enache, L., Biofizică, vol. 1, Editura didactică şi pedagogică S.A., Bucureşti, 2004 
14. Enache L. , Biofizică, vol. 2. Editura Universității "Spiru Haret”, Bucureşti, 2005.

15. Enache L., Filipescu C., Simionca Iu. (Ghe.) and al.: Natural and artificial air ionization in underground spaces - an environmental factor with therapeutic potential. 14th International Congress of Speleology. Athens-Kalamos, 21-28 August 2005. Congress Proceedings, CD, Folder FULL PAPERS, Microsoft Word Document 189 Full Paper, p. 1-5.

16. Hematological Values for Long Evans Rats. Hematological Values for Wistar-Kyoto Rats. TACONIC. ANTECH diagnosis, 10 Executive Blvd. Farmingdele. Nz 11735. HTML Document, 2006.

17. Krueger A.P., Smith R.F. The physiological significance of positive and negative ionization of the atmosphere. in mans dependence on the earthly atmosphere Proceedings of the First International Symposium on Submarine and Space Medicine.

Edited by Karl E. Schaefer, 1958, The MacMillan Company, pp. 356-369.

18. Krueger A.P., Smith R.F.The biological mechanisms of air ion action
Reprinted from the Journal of General Physiology, January, 1960

Vol. 43, No. 3, pp. 533-540 (U.S.A.).

19. Krueger, A. P. (1976). Biological effects of ionization of the air on animals Progress on Biometeorology: The Effect of Weather and Climate on Animals. Chapter 5, Section 1, Swets \& Zeitlinger, B.V., Amsterdam, pp. 155-162 (1976).

20. Puggina Rogato Gustavo, Elite Luciano. Leukocytes profile of rats (Rattus norvegicus albicans, Wistar). Submited to chronic resistence exercise. FAPESP / grant no 00/01804-6. Universitode Estadual Paulista. Abstracts. Volume 18, n. 1, HTML Document 2006.

21. Soyka F. şi Edmonds A., 1977, The Ion Effect, Dutton \& Co. Publ. N.Y., 181 pp, Sulman, F.G. (1976), Health, Weather and Climate, Karger, Baswel, p.160.

22. Tchijevski A. L. Les phénoménes électrodynamiques dans le sang et le moyen de les diriger. Ed. Le Francois 1963, Paris. UCHA UBADE R., UCHA UBADE M. Significado biológico de la aeroionización, su relación con las neurohormonas, Semana Méd., 1963, 122, 1399. 